\title{
Działalność Augustinasa Voldemarasa jako kreatora litewskiej polityki zagranicznej wobec Polski, Niemiec i ZSRR w latach 1926-1929
}

Zarys treści: Po zamachu stanu w grudniu 1926 r. na czele Litwy stanęli liderzy partii narodowców: Augustinas Voldemaras i Antanas Smetona. W artykule omówiono politykę zagraniczną Voldemarasa w kluczowych dla Litwy latach 1927-1928. Był to okres próby przebudowy stosunków relacji polsko-litewskich, głównie w kontekście Wileńszczyzny, tajnych negocjacji z Niemcami, mających na celu pozyskanie dodatkowego wsparcia finansowego dla młodego państwa litewskiego oraz polityki zbliżenia z ZSRR, dzięki której Litwa zyskała potężnego sojusznika w sporze z Polską.

Outline of content: Following the coup d'état of December 1926, Lithuania found itself governed by the leaders of the Lithuanian Nationalists, Augustinas Voldemaras and Antanas Smetona. The article discusses Voldemaras' foreign policy during the important for Lithuania years of 1927 and 1928. It was the period of attempted reconstruction of Polish-Lithuanian relations, mainly in the context of Vilnius region, secret negotiations with the Germans to secure additional financial support for the young Lithuanian state, and policy of détente with the USSR which made it possible for Lithuania to gain a powerful ally in the argument with Poland.

Słowa kluczowe: Augustinas Voldemaras, stosunki litewsko-polskie, stosunki litewsko-niemieckie, stosunki litewsko-sowieckie, litewska polityka zagraniczna 1926-1928, Wileńszczyzna, Kłajpeda

Keywords: Augustinas Voldemaras, Polish-Lithuanian relations, Lithuanian-German relations, Lithuanian-Soviet relations, Lithuanian foreign policy 1926-1928, Vilnius region, Klaipeda

\section{Wstęp}

W nocy z 16 na 17 grudnia 1926 r. na Litwie doszło do wojskowego zamachu stanu. Władzę w kraju przejęli liderzy partii narodowców - dr Antanas Smetona i prof. Augustinas Voldemaras. Ówczesny prezydent Kazys Grinius podał się do 
dymisji, nowa ekipa rządząca rozpoczęła zaś przebudowę systemu politycznego zmierzającego do wprowadzenia na Litwie reżimu autorytarnego ${ }^{1}$.

Profesor Voldemaras objął dwa ważne stanowiska rządowe - został ministrem spraw zagranicznych oraz premierem. Na początku kadencji jego głównym obszarem działalności była polityka wewnętrzna państwa, co nie pozwalało mu na dostateczne skupienie się na kwestiach związanych z polityką zagraniczną, w konsekwencji czego 27 kwietnia 1927 r. utworzono stanowisko sekretarza generalnego Ministerstwa Spraw Zagranicznych (MSZ). Pierwszym wiceministrem został Bronisław Kazimierz Balutis ${ }^{2}$. Zmiany w strukturze rządu umożliwiły Voldemarasowi realizację zasadniczych funkcji reprezentacyjnych na forum międzynarodowym, m.in. branie aktywnego udziału w posiedzeniach Ligi Narodów (LN) oraz prowadzenie negocjacji dyplomatycznych z szefami rządów oraz ministrami spraw zagranicznych. Nowa struktura resortu spraw zagranicznych na Litwie zawierała w sobie takie elementy, jak departament polityki i ekonomii na czele z dyrektorem Balutisem, departament przy LN z Ignasem Jonynasem, departament prasy i informacji, gdzie funkcję dyrektora sprawowała Magdalena Avietenaitė oraz departament administracji, którego szefem został Jurgis Sawickis. Narodową litewską agencją prasową (ELTA), będącą pod auspicjami Ministerstwa Administracji, zarządzał Antanas Jakobas.

Postępujący deficyt w budżecie państwa skłonił Voldemarasa do stworzenia planu oszczędnościowego oraz reorganizacji bazy placówek dyplomatycznych zlikwidowano ambasady w Genewie, Sztokholmie, Pradze oraz Helsinkach ${ }^{3}$. Część pracowników została przeniesiona do struktur MSZ lub innych urzędów przedstawicielskich.

Najbliższe otoczenie mogło postrzegać Voldemarasa jako osobę konsekwentną i skrupulatną. W kontaktach interpersonalnych utrzymywał dystans, tworząc tym samym wizerunek osoby bezkompromisowej, zasadniczej, zdecydowanej, konserwatywnej, wymagającej oraz nieznoszącej krytyki i pozbawionej dystansu do siebie. Cechy te były również zauważalne $\mathrm{w}$ prowadzonej przez niego polityce wewnętrznej, o czym mogą świadczyć m.in. plany naprawcze, jakie wprowadził już na początku swojej kadencji ${ }^{4}$.

\section{Kwestia Wileńszczyzny jako początek działalności premiera}

Trzy dni po zamachu stanu, 20 grudnia 1926 r. odbyła się konferencja prasowa, na której Voldemaras jako nowy premier Litwy wygłosił exposé. Dobitnie podkreślił,

\footnotetext{
1 „Memeler Dampfboot” (1 I 1927), nr 1.

2 B.K. Balutis, Jo gyvenimas ir darba, Michigan 1951, s. 96.

${ }^{3}$ Lietuvos Centrinis Valstybes Archyvas (dalej: LCVA), f. 383, AP. 7, B. 727, B.K. Balucio 1927 r. birzelio 28 d. laisko J. Aukstuoliui i Ryga nuorasas, s. 64 .

${ }^{4}$ Pamiętniki A. Voldemarasa, Pastabas saulèlydžio valandą, Vilnius 1992, s. 208.
} 
iż stosunki dyplomatyczne z Polską zostaną unormowane po rozwiązaniu kwestii Wileńszczyzny. Zaznaczył, iż wyjaśnienie tego problemu będzie zadaniem priorytetowym w aktualnej polityce zagranicznej Litwy oraz że pozostawienie Wilna w granicach Polski rząd litewski traktuje jako zdradę państwową ${ }^{5}$.

Należy podkreślić w tym miejscu, że ze strony państw Europy Zachodniej wyczuwalne były duże oczekiwania względem nowego rządu litewskiego w zakresie progresu w obszarze normalizacji stosunków między Litwą a Polską. Nieprzypadkowo stanowczy wydźwięk exposé Voldemarasa spotkał się z negatywnym odbiorem wśród polityków w Paryżu, Londynie oraz Waszyngtonie, dodatkowo ulegając wzmocnieniu $z$ uwagi na zapowiedź premiera, iż Litwa nawiąże stosunki dyplomatyczne z tymi państwami, które uznają przynależność Wilna do terytorium Litwy ${ }^{6}$. Oświadczenie Voldemarasa negatywnie wpłynęło na pozycję Litwy na arenie międzynarodowej, co w następstwie skutkowało zauważalną, stopniową izolacją tego państwa w stosunkach międzynarodowych.

Zaistniała sytuacja mogła być wykorzystana przez rząd Polski na jego korzyść, co niejednokrotnie podkreślano w prasie litewskiej. W północno-wschodniej części Litwy na linii demarkacyjnej zostały rozlokowane dobrze uzbrojone i przeważające liczebnością polskie jednostki militarne. Wojsko otrzymało od Marszałka Józefa Piłsudskiego wyraźną instrukcję podjęcia akcji militarnej w przypadku wystąpienia prowokacji na linii demarkacyjnej ${ }^{7}$. Na lamach litewskich gazet pojawiały się nagłówki głoszące, iż Polsce wystarczy niewielki pretekst, by podjąć działania zbrojne, wzbudzając tym samym w obywatelach poczucie poważnego zagrożenia ze strony zachodniego sąsiada. Po drugiej stronie linii demarkacyjnej panowało przekonanie, że w razie potencjalnej akcji militarnej odpowiedzialność za wywołanie konfliktu spocznie na Litwie, gdyż ta będzie uznana za inicjatora prowokacji. Równocześnie w prasie polskiej pojawiały się nagłówki ostrzegające o możliwości podjęcia prób wywołania konfliktu przez stronę litewską, co dodatkowo potęgowało przekonanie wśród opinii publicznej, że to Litwa odpowiada za napiętą sytuację pomiędzy sąsiadami ${ }^{8}$. Związek Narodowców (litewska partia rządząca) wychodził zaś $\mathrm{z}$ założenia, że polskie ambicje imperialistyczne $\mathrm{w}$ stosunku do Litwy stopował niesprecyzowany stosunek Niemiec do istniejącego status quo, czego efektem było zachowawcze wyczekiwanie strony polskiej na ruch wschodniego sąsiada.

Tymczasem Związek Radziecki realizował własne cele polityczne na Litwie, wspierając nacjonalistyczno-antypolską politykę zagraniczną Voldemarasa. Tuż po zamachu stanu na demokratyczny rząd Mikołaja Sleževičiusa, rząd radziecki 19 grudnia 1926 r . na łamach gazety „Izvestija” zapowiedział, iż zamierza wspierać

${ }^{5}$ R. Žepkaité, Konflikto tarp Lietuvos ir Lenkijos paastrejimas 1927 r. ir Tarybu Sajungos Pozicija, „Lietuvos Istorijos Metrastis” (1972), s. 90.

6 J. Skirius, Lietuvos uztalantes diplomatija, 1918-1929 m., Vilnius 1995, s. 98.

7 P. Łossowski, Po tej i tamtej stronie Niemna. Stosunki polsko-litewskie 1883-1939, Warszawa 1985, s. 221.

8 A.E. Senn, The Great Powers, Lithuania and the Vilna Question 1920-1928, Leiden 1966, s. 185. 
nowy rząd Litwy, szczególnie w zakresie regulacji kwestii związanej z Wileńszczyzną. Voldemaras, świadomy wsparcia płynącego z ZSRR, wykorzystywał relacje z Polską do osiągnięcia osobistych korzyści politycznych. Doskonale wiedział, że władze Związku Radzieckiego będą wspierały antypolską retorykę, tym bardziej że od 1920 r. w ZSRR również panowały nastroje antypolskie. Umocnienie pozycji Litwy zarówno w stosunkach z Republiką Weimarską, jak i ZSRR dało Voldemarasowi możliwość zredefiniowania bieżącej polityki zagranicznej. W kolejnych latach sprawowania rządów polityk stosował taktykę płynnego lawirowania pomiędzy dwoma sojusznikami, zapewniając Litwie osiągnięcie możliwie największych korzyści zarówno politycznych, jak i gospodarczych. W stosunkach z Polską można przyjąć założenie, że de facto cel polityka stanowiło utrzymywanie napiętych relacji i zachowanie przyjętego modus vivendi oraz możliwie najdłuższe przeciąganie w czasie unormowania wzajemnych relacji między sąsiadami. Należy zastanowić się, jakie były okoliczności prowadzenia $\mathrm{w}$ ten sposób polityki zagranicznej przez Voldemarasa. Niewątpliwie czynniki silnie oddziałujące w tym zakresie to z jednej strony stosunek sił zbrojnych Litwy do Polski, wynoszący $1: 10$, z drugiej nadejście nowej ery w prowadzeniu polityki międzynarodowej, gdzie po I wojnie światowej zauważalne było odejście od stosowania polityki przymusu przez państwa trzecie względem niepodległych jednostek. Zastana sytuacja międzynarodowa pozwalała zatem Voldemarasowi na kontynuowanie prowadzenia polityki napiętych stosunków ze stroną polskąa .

Stosunek ZSRR do Litwy z tamtego czasu najlepiej był widoczny w artykułach prasowych oraz encyklopediach. W jednej z nich, z 1938 r., pod hasłem „Litwa” można przeczytać: „[Litwa] jest państwem o przestarzałej gospodarce agrarnej. Przemysł bardzo słabo rozwinięty. Handel znajduje się w rękach skrajnych rządowych nacjonalistów. Życie klasy średniej tj. robotników i rolników, a w szczególności kowieńskiej masy chłopskiej, plasuje się na bardzo niskim poziomie ekonomicznym"10.

Pierwszym krokiem w kierunku politycznego zbliżenia się z Sowietami było wygłoszone przez Voldemarasa exposé 21 grudnia 1926 r., w którym zapowiedział, że nowo utworzony gabinet nie zamierza wprowadzać zmian do paktu gwarancyjnego zawartego z Moskwą 28 września 1926 r. ${ }^{11}$ Premier Litwy wyraził również nadzieję, że przywołany dokument będzie podstawą do utrzymania przyjaznych relacji między stronami ${ }^{12}$. Pakt litewsko-radziecki, podpisany jeszcze za czasów

9 R. Žiugžda, Lietuva imperialistiniu valstybiu planuose 1917-1940, Vilnius 1983, s. 71.

10 L. Mitkiewicz, Litwa i Polska. Stosunki wzajemne do roku 1939, Toruń 2018, s. 150.

1128 września 1926 r. po długich negocjacjach w Moskwie zawarto pakt o nieagresji i neutralności między Litwą a ZSSR. Umowa została podpisana przez uprzedniego premiera Litwy Sleževičiusa oraz członka Centralnego Komitetu Wykonawczego ZSSR Gieorgija Cziczerina. Największym zwycięstwem rządu litewskiego było to, iż w treści paktu uznano obszar Wileńszczyzny za terytorium należące do Litwy.

12 V. Sirutavipius, E. Nekrašas, R. Lopata, Svarbiausiosios Lietuvos Respublikos tarptautinơs sutartys 1918-1995 r., Vilnius 1997, s. 31-33. 
rządów Sleževičiusa, miał wyraźnie antypolski wydźwięk i stanowił niejako bazę polityki zagranicznej Voldemarasa. 30 grudnia 1926 r. w odpowiedzi na démarche wystosowane przez rząd sowiecki, odnoszące się do wszczęcia II etapu negocjacji w sprawie zawarcia umów handlowych, premier w obawie, iż Litwa uzależni się politycznie i gospodarczo od ZSRR, postanowił odrzucić dokument. Z Moskwy odwołano delegację litewską, która $\mathrm{w}$ drugiej połowie grudnia rozpoczęła rokowania z rządem radzieckim, dotyczące przyszłych umów handlowych. Premier Litwy wystosował również notę do Moskwy, w której zaznaczył, iż wzajemne relacje są na niewystarczająco zaawansowanym etapie, by zacieśniać więzi gospodarcze między dwoma państwami. Nota zawierała także zapowiedź ponownego podjęcia rozmów, gdy te w sposób naturalny będą tego wymagały ${ }^{13}$.

Polityka „dobrego sąsiedztwa” z ZSRR nie rozeszła się bez echa w prasie zarówno polskiej, jak i zachodniej. Mocarstwa zachodnioeuropejskie dążyły do włączenia Litwy do bloku państw cordon sanitaire, by ta stanowiła jedno z państw buforowych (m.in. wraz z Polską) dla Zachodu, odgradzając go od potencjalnego zagrożenia ze strony Republiki Weimarskiej, a de facto od Związku Radzieckiego - zagrażającego Europie zarówno pod względem militarnym, jak i ideologicznym. Rządy Wielkiej Brytanii, Francji oraz Włoch postanowiły dołożyć wszelkich starań, by powstrzymać Litwę od zawarcia koalicji ze Związkiem Radzieckim oraz ewentualnego sprzymierzenia się z Republiką Weimarską. Celem realizacji przyjętych założeń mocarstwa zachodnie 19 lutego 1927 r., za pośrednictwem ambasadorów akredytowanych w Kownie, wystosowały notę do premiera Litwy, w którym domagały się ustabilizowania sytuacji na Wschodzie, m.in. poprzez normalizację stosunków z Polską. Należy przypomnieć, iż podobna deklaracja została wręczona delegacji litewskiej 12 lutego 1927 r. w Warszawie przez ministra spraw zagranicznych Augusta Zaleskiego. Szef polskiego MSZ 12 lutego zwrócił się w oficjalnej nocie dyplomatycznej do Voldemarasa, domagając się unormowania stosunków polityczno-gospodarczych z Polską oraz starając się nakłonić rząd w Kownie do zreformowania systemu politycznego, by ten nie różnił się znacząco od zachodnich demokracji. W odpowiedzi Voldemaras jako szef rządu litewskiego 25 lutego 1927 r. wystosował pismo, w którym zwrócił się do LN oraz polskiego MSZ: „Litwa jest niezawisłym i niepodległym państwem ze stolicą w Wilnie, co ostatecznie zostanie osiągnięte przy użyciu rozmaitych metod i środków”. W dalszej części dokumentu premier Litwy zapewniał, iż jego rząd jest gotów podjąć rokowania z Polską celem nawiązania przyjaznych i pokojowych stosunków, tak ważnych dla budowy sprawiedliwego i pokojowego ładu europejskiego: „Osobiście zobowiązuję się prowadzić rokowania w tej kwestii z Polską, pod warunkiem, iż rokowania te będę zmierzać w kierunku realizacji naszego programu rządowego" ${ }^{14}$. Zauważyć tu można bezkompromisową pozycję negocjacyjną Voldemarasa w kwestii Wilna,

\footnotetext{
13 Ibidem, s. 72.

14 R. Žepkaité, Konflikto tarp Lietuvos..., s. 90.
} 
na którą zwraca uwagę również Piotr Łossowski w książce pt. Stosunki polsko-litewskie 1921-1939. Równie wartościowy wydaje się ściśle tajny list napisany przez Dominike Moratha do litewskiego premiera - dokument obecnie znajduje się w Państwowym Archiwum Historycznym w Wilnie. W liście Morath wymienił korzyści płynące dla Litwy ze strony rządu Republiki Weimarskiej w zamian za utrzymanie realizowanej polityki negocjacyjnej w rozmowach z Polską.

Morath, pełniący funkcję sekretarza generalnego Republiki Weimarskiej, niejednokrotnie kontaktował się z premierem Litwy, m.in. jako przedstawiciel MSZ Republiki Weimarskiej - Ericha Wallrotha. Przekazał wówczas Voldemarasowi instrukcje dotyczące prowadzenia rozmów dyplomatycznych podczas rokowań z Polską. W jednym z listów znajdują się następujące ustalenia strony litewskiej oraz niemieckiej odnoszące się do Polski:

Panu Prof. A. Voldemarui Poufne

Premier i Minister Spraw Zagranicznych Kowno

D. Morath'a

Konferencja z Auswiertiges

Amt'u wyniki.

W zeszłym tygodniu w sobotę miałem okazję poświęcić wiele godzin na rozmowę $\mathrm{z}$ wiceministrem Carlem Von Schubertem, wczoraj po południu około 2 godzin spędziłem z ministrem Wallrothem. $Z$ rozmów $\mathrm{z}$ nimi wyciągnąłem następujące wnioski:

Pan Morath w rozmowie z ministrem Wallrothem i z sekretarzem państwowym V. Schuberetem wynegocjowali dla Litwy od strony niemieckiej następujące korzyści:

1. Postanowiono wspierać obecny rząd litewski i udzielić mu pełnomocnictwa do regulacji kwestii stosunków politycznych i ekonomicznych.

2. Dokładać starań aby utrzymywać dyskretne stosunki z Litwą.

3. Rozwiązanie nieporozumień dotyczących kwestii Kłajpedy oraz udzielenie wskazówek stronie litewskiej w zakresie utrzymywania stosunków politycznych z Polską oraz Europą Wschodnią.

4. Uregulowanie powziętych zobowiązań finansowych przez Reichsbank, oraz utworzenie bieżącego konta w Centralnym Banku Litwy. Ustalenie w jakim rodzaju i formie Niemiecki Reichsbank i pozostałe niemieckie banki będą mogły pomóc finansowo Litwie. W tym celu proponuje się przybycie do Berlina zarządcy Centralnego Banku Litwy prof. Vladasa Jurgutisa w celu prowadzenie dalszych negocjacji w kwestii procedury ewentualnego wsparcia finansowego ${ }^{15}$.

Warto zwrócić uwagę, że poseł RP w Berlinie Kazimierz Olszowski już 7 października 1927 r. meldował, że prawicowy rząd w tym mieście dąży do zaognienia stosunków na linii Warszawa-Kowno. Priorytetem rządu niemieckiego było doprowadzenie do wybuchu konfliktu z ZSRR w przypadku podjęcia jakichkolwiek działań wobec Litwy przez Polskę ${ }^{16}$.

15 LCVA, f. 671, Ap. 1, B. 5, L. 289.

16 Archiwum Akt Nowych (dalej: AAN), Ministerstwo Spraw Zagranicznych (dalej: MSZ), t. 4497, s. 36 . 
Otrzymawszy instrukcje od Wallrotha, rząd w Kownie, z Voldemarasem na czele, postanowił uzupełnić démarche z 25 lutego 1927 r. o dwa istotne punkty, które miały zostać zaakceptowane przed rozpoczęciem pertraktacji z Warszawą. Po pierwsze, rząd w Warszawie powinien orzec, iż kwestia Wileńszczyzny nie jest de facto sprawą rozwiązaną do końca. Po drugie, Warszawa winna uznać Litwę de iure. Voldemaras zaznaczył, iż strony nie są ze sobą w stanie wojny, dlatego Litwa podjęła dobrowolne kroki celem pertraktacji prowadzących do uregulowania i normalizacji stosunków polsko-litewskich. Deklaracja ta nie została jednak udokumentowana w żadnej oficjalnej nocie, co dla marszałka Józefa Piłsudskiego oznaczało, że deklaracja nie miała mocy prawnej, a relacje między sąsiadami nadal przypominały stan wojenny ${ }^{17}$. Piłsudski po przewrocie majowym z 12-15 maja 1926 r. przejął władzę w Polsce. Jednym z celów Marszałka była normalizacja napiętych stosunków polsko-litewskich, wymagająca porzucenia przez niego nierealistycznej koncepcji federacyjnej ${ }^{18}$.

Polski MSZ 14 maja 1927 r. wystosował odpowiedź na litewskie démarche otrzymane w lutym. W dokumencie podkreślił wolę normalizacji stosunków sąsiedzkich z Litwą pod warunkiem, iż kwestia Wileńszczyzny zostałaby pominięta ${ }^{19}$. Miesiąc później w czerwcu 1927 r. polski resort MSZ przedstawił Francji i Litwie projekt nawiązania stosunków polsko-litewskich, w którym obydwie strony uznałyby się de iure i wyraziłyby chęć nawiązania przyjaznych stosunków ${ }^{20}$.

Stanowiska przyjęte przez obie strony nie pozwoliły na poczynienie postępów w zakresie normalizacji stosunków polsko-litewskich, jednocześnie zminimalizowały częstotliwość nacisków wywieranych przez mocarstwa zachodnie na Litwę. Politycy zachodnioeuropejscy aktywnie angażowali się w proces mediacji pomiędzy sąsiadami, najmocniej zaś Francja będąca pod naciskiem Marszałka Piłsudskiego. Plan polskiego Naczelnika Państwa zakładał próbę wpłynięcia na Voldemarasa za pośrednictwem francuskiego posła w Kownie Gabriela Puauxa ${ }^{21}$, który dzięki bliskiej znajomości z litewskim premierem miał namówić go do zaprzestania działań zmierzających do wprowadzenia stanu wojennego ${ }^{22}$.

W czerwcu 1927 r. tuż po zakończeniu sesji wiosennej Rady LN Voldemaras udał się do Paryża, gdzie spotkał się z ministrem Zaleskim oraz sekretarzem generalnym francuskiego MSZ Elanem Bertelem. Na spotkaniu szef polskiego MSZ złożył deklarację, iż rząd polski uznaje i respektuje całkowitą niepodległość i jedność

17 P. Łossowski, Dylematy polsko-litewskie. Początki zatargu. Miejsce Józefa Piłsudskiego w konflikcie, w: Stosunki polsko-litewskie wczoraj i dziś. Historia, kultura, polityka, red. nauk. W.K. Roman, J. Marszałek-Kawa, Toruń 2009, s. 58.

${ }^{18}$ L. Wyszczelski, Federacja czy inkorporacja, „Wojsko i Wychowanie” (1992), nr 4, s. 42.

19 R. Žepkaité, Konflikto tarp Lietuvos..., s. 91.

20 AAN, MSZ, t. 6104, s. 29.

${ }^{21}$ J. Laroche, Polska lat 1926-1935. Wspomnienia ambasadora francuskiego, przeł. i oprac. S. Zabiełło, Warszawa 1966, s. 61.

22 A.E. Senn, op. cit., s. 187. 
terytorialną Republiki Litewskiej. Główny tematem rozmów była kwestia uruchomienie tranzytu Niemnem, na co premier Litwy wyraził zgodę ${ }^{23}$. Mając na uwadze silną pozycję negocjacyjną Voldemarasa, można przypuszczać, że z uwagi na obecność francuskich mediatorów zakładał on, iż kwestia Wileńszczyzny spotka się ze specjalnym traktowaniem podczas zaplanowanych obrad.

Ustępstwa w zakresie otworzenia tranzytu Niemnem wywołały burze w Kownie. Wszczęto spekulacje, jakoby premier prowadził tajne negocjacje $\mathrm{z}$ ministrem Zaleskim w Paryżu. Gdy 22 czerwca 1927 r. Voldemaras wrócił do Kowna, na dworcu kolejowym przywitało go wojsko wraz z dowódcami sił zbrojnych, dając tym samym wyraz sprzeciwu w stosunku do polityki zbliżenia z Polską. Pod wpływem silnych nacisków ze strony litewskich elit, 30 czerwca Voldemaras wycofał się z podjętych w Paryżu ustaleń, o czym poinformował ministra Zaleskiego w stosownym piśmie. Francuski ambasador w Kownie Puaux wyraził się negatywnie o zaistniałej sytuacji, uznając ją równocześnie za osobistą porażkę. Najlepiej ogląd tamtejszej sytuacji oddają wspomnienia Vaclovasa Sidzikauskasa (litewskiego dyplomaty), który napisał, iż Voldemaras odniósł się do całej sytuacji w sposób iście cyniczny, odpowiadając francuskiemu dyplomacie: „Sz. P. Puaxe, źle Pan mnie zrozumial" 24 .

20 lipca 1927 r. Związek Narodowców kategorycznie zaprzeczył wszystkim pogłoskom dotyczącym prowadzenia przez rząd litewski ściśle tajnych negocjacji z Polską, uspokajając tym samym wojsko i opinię publicznąą.

Eskalacja konfliktu między Polską a Litwą osiągnęła swój szczyt we wrześniu 1927 r., gdy na łamach prorządowej, prawicowej prasy pojawiły się informacje o antylitewskiej działalności polskich dyplomatów w okręgu wileńskim. Zdaniem dziennikarzy 9 października i 23 listopada w Wilnie polskie struktury wojskowe na Litwie $\mathrm{z}$ inspiracji Piłsudskiego podjęły debatę nad tym, w jaki sposób najefektywniej pokonać litewskie siły zbrojne ${ }^{26}$. Łossowski przyczyn eskalacji konfliktu polsko-litewskiego dopatruje się w wydarzeniach z 6 sierpnia 1927 r., kiedy to litewskie Ministerstwo Oświaty wdrożyło reformy mające na celu znaczne ograniczenie liczby patentów przyznawanych pedagogom, zmniejszając tym samym liczbę polskich nauczycieli i szkół na Litwie ${ }^{27}$. Odmiennego zdania jest natomiast Česlovas Laurinavičius, który początku kryzysu stosunków polsko-litewskich doszukuje się w publikacji w prasie polskiej „Listu 28” z początku października $1927 \mathrm{r}$. List ten stanowi świadectwo trudnych warunków życia polskich nauczycieli więzionych $\mathrm{w}$ obozie koncentracyjnym $\mathrm{w}$ Worniach (obecnie wieś w rejonie trockim). Według litewskiego badacza Alfredasa Erichasa Senasa list ten był falsyfikatem, co więcej,

\footnotetext{
23 V. Sidzikauskas, Lietuvos diplomatijos paraštèje, Vilnius 1994, s. 103.

24 Ibidem, s. 104.

25 „Lietuvis” (20 VII 1927), nr 178.

26 A. Garlicki, Józef Piłsudski 1867-1935, Warszawa 1989, s. 482.

27 Z. Budecki, Stosunki polsko-litewskie po wojnie światowej 1918-1928, Warszawa 1928, s. 78.
} 
został przygotowany osobiście przez Marszałka Piłsudskiego celem wywołania konfliktu i wzięcia odwetu na litewskiej inteligencji ${ }^{28}$.

15 października 1927 r. do Rady LN wpłynęła skarga złożona przez Voldemarasa. Litewski premier oskarżał rząd w Warszawie o niedotrzymanie warunków umowy z 25 czerwca 1919 r. w zakresie ochrony mniejszości narodowych oraz o spiskowanie przez Piłsudskiego przeciwko Litwie. Voldemaras w piśmie zaznaczał, że Litwa jest zagrożona zarówno polonizacją od wewnątrz, jak i agresją ze strony Marszałka $^{29}$. Co ciekawe, Voldemaras był świadomy, iż Polska nie zagrażała Litwie $\mathrm{w}$ tamtym czasie. Potwierdzenie może stanowić ściśle tajna korespondencja pomiędzy Voldemarasem, Morathem i niemieckim kontrwywiadem. Poniższa depesza została przekazana Voldemarasowi 7 października 1927 r.:

\section{Poufne}

Szanowny Panie Dyrektorze Departamentu Politycznego Kowno

Otrzymawszy Pana telegram Nr. 15 oraz będąc na wizycie u Dyrektora Departamentu Sz. P. Wallroth'a, chciałem poinformować oraz dowiedzieć się, czy nie posiada Ausw. Amt. informacji o szykowanej przez Polskę ewentualnej agresji lub prowokacji przeciwko Litwie. Jednakże Sz. P. Wallroth poinformował mnie poprzez nadesłany telegram, iż nie ma dla Litwy takich negatywnych wieści, wszakże poselstwo Niemiec w Warszawie nic nie podało do wiadomości. Sz. P. Wallroth zapewnił, iż tą kwestią jest bardzo zainteresowane centrum Berlina i wszakże jak najbardziej zapewnia, że Litwie nie grozi niebezpieczeństwo ${ }^{30}$.

Rada LN umieściła skargę Voldemarasa w protokole porządku obrad sesji na 7 grudnia 1927 r. ${ }^{31} \mathrm{~W}$ tym miejscu należy zastanowić się, jakie partykularne korzyści od Rady LN pragnął uzyskać Voldemaras?

W pamiętnikach z 1940 r., pisanych podczas pobytu w więzieniu NKWD w Ordżonikidze (Osetia Północna), premier Litwy stwierdzał: „osobiście nie pokładałem nadziei w Lidze Narodów, w swoich działaniach starałem się zwrócić uwagę opinii międzynarodowej na narastający konflikt polsko-litewski w celu usankcjonowania go na forum międzynarodowym, czego efektem miało być pojawianie się tej kwestii wśród tytułów artykułów zachodniej prasy"32. Natomiast według litewskiego posła akredytowanego przy ambasadzie w Paryżu, Petrasa Klimasa: „Ten «stan wojny», który eksponował Voldemaras nie był dobrze odbierany wśród zachodnich dyplomatów, dążących do utrzymania pokojowych stosunków wśród państw europejskich. Można było odnieść wrażenie, że cała LN przegotowywała przeciwko nam wojnę krzyżową". Klimas próbował przekonać Voldemarasa, by ten wycofał swoją notę z 15 października i wznowił negocjacje z polską delegacją,

28 A.E. Senn, op. cit., s. 239.

29 K. Skirpa, Pakeliui su Mykolu Slezevicium, Chicago 1951, s. 257.

${ }^{30}$ LCVA, f. 671, Ap. 1, B. 5, L. 15.

31 V. Sidzikauskas, op. cit., s. 104.

32 A. Voldemaras, Pastabos saulèlydžio valandą, Vilnius 1992, s. 83. 
nawet pomimo braku przychylności francuskiego dyplomaty Puauxa. Promemoria Klimas zakończył słowami: „nasz rząd z Voldemarasem na czele nie cieszy się dobrą opinią wśród państw Ligii Narodów, przez co organ ten będzie zmuszony podjąć decyzję, czy poddać na forum Ligi kwestię dalszego członkostwa Litwy w tejże organizacji”" ${ }^{33}$.

Mocarstwa zachodnie w miesiącach październik-listopad 1927 r. podjęły próby łagodzenia konfliktu polsko-litewskiego. W negocjacjach większy nacisk położono na ustępstwa wobec rządu w Kownie. W tym celu Voldemaras wystosowawszy za pośrednictwem ambasadorów akredytowanych w Kownie do państw zachodnich memorandum z 27 października 1927 r., po raz kolejny podkreślił swoją bezkompromisowość $\mathrm{w}$ zakresie normalizacji stosunków z Polską. We wspomnianym dokumencie premier Litwy przedstawił genezę konfliktu z Polską, w charakterystyczny sobie sposób oskarżając o utrzymywanie istniejącego stanu przez rząd w Warszawie. Zasadniczy punkt memorandum stanowiło wskazanie, iż uregulowanie i normalizacja stosunków na linii Kowno-Warszawa są możliwe poprzez rozwiązanie kwestii granicy północno-wschodniej pomiędzy Republiką Litewską a Rzecząpospolitą Polską. Voldemaras zasugerował tym samym stronie polskiej, by sporne kwestie rozwiązać w pertraktacjach na sesji LN 7 grudnia 1927 r. Treść memorandum została skrytykowana przez zachodnich dyplomatów, którzy nie odnieśli się do niego w sposób pożądany przez premiera Litwy ${ }^{34}$. Pomimo starań polskiego ambasadora w Wielkiej Brytanii Konstantego Skirmunta nie udało się wywołać protestu ze strony mocarstw zachodnich, a w szczególności brytyjskiego Foreign Office wobec dokumentu wystosowanego przez Voldemarasa, argumentując to wchodzeniem w zakres kompetencji Rady $\mathrm{LN}^{35}$.

Z podobną sytuacją spotkał się również Witold Czerniewski - ambasador Litwy $\mathrm{w}$ Rzymie, poinformowany przez tamtejszy rząd, iż w memorandum zarówno z 15, jak i 27 października brakuje wyrażenia przez rząd litewski chęci do pokojowego rozwiązania sprawy. Ponadto źródła włoskiego MSZ wskazywały na to, że Wielka Brytania i Francja są przekonane o nieczystych intencjach premiera Litwy ${ }^{36}$. Antonio Garigalia, generalny dyrektor włoskiego resortu MSZ, po konsultacjach z Czerniewskim zalecił Voldemarasowi, aby litewski minister wykazał się większą skłonnością do ustępstw podczas grudniowej sesji genewskiej.

Marszałek Piłsudski nie pozostał obojętny na litewskie memorandum. W tym miejscu warto przytoczyć wywiad z Marszałkiem z 30 listopada 1927 r., który ukazał się w prasie polskiej, jednak jego adresatami byli obywatele zarówno polscy, jak i litewscy. Piłsudski podkreślił w nim, że Kowno prowokuje Warszawę do podjęcia działań zbrojnych, odnosząc się negatywnie m.in. do rozpoczętej

33 „Voruta” (23 III 2003), nr 6 (504), s. 4.

${ }^{34}$ R. Žepkaité, Konflikto tarp Lietuvos..., s. 95.

35 AAN, Ambasada w Londynie, t. 350, s. 102.

${ }^{36}$ Ibidem, s. 96. 
w Polsce mobilizacji sił zbrojnych. Treść fragmentu wywiadu Marszałka, w którym Naczelnik Państwa nie szczędził słów krytyki dla litewskiego premiera, została opublikowana przez litewski organ rządowy „Lietuva”: „od prof. Voldemarasa wszystkiego możemy oczekiwać, jest politykiem nieodpowiedzialnym, ten litewski patriota, przez jakiś czas był Rosjaninem, później Niemcem, ostatecznie zlitwinizował się - jest to zjawisko chorobliwe”. Marszałek będąc „,Zwolennikiem pokoju”, zamierzał wziąć udział w sesji genewskiej 10 grudnia 1927 r. Zapowiedź spotkania Piłsudskiego z Voldemarasem wzbudzała zainteresowanie mediów podnoszących w swych artykułach temat konfliktu polsko-litewskiego ${ }^{37}$.

Litewski premier udał się na Zachód celem prowadzenia dalszych negocjacji. 7 grudnia miał zjawić się na kolejnej sesji Rady LN. W drodze do Genewy zatrzymał się w Berlinie, gdzie 5 grudnia spotkał się z niemieckim sekretarzem stanu Karlem Schubertem. Podczas zamkniętego spotkania polityków Voldemaras oznajmił, iż w Genewie chce ograniczyć się do kwestii zamykania przez polskie władze litewskich szkół w Wilnie. Schubert przekonywał premiera Litwy, aby ten w trakcie posiedzenia Rady LN złożył oświadczenie o braku stanu wojny pomiędzy Litwą a Polską. Voldemaras początkowo odrzucił taką ewentualność, jednakże linia argumentacyjna wytoczona przez Schuberta ostatecznie przekonała premiera Litwy do podjęcia działań w tym zakresie. Zaznaczył on jednak, że nie zamierza tym samym nawiązywać stosunków dyplomatycznych z Polską, ograniczając się jedynie do złożenia deklaracji o pokojowym nastawieniu względem zachodniego sąsiada $^{38}$. W tym samym dniu Voldemaras odbył również spotkanie z Gustavem Stresemannem, który sugerował premierowi Litwy złożyć oświadczenie na sesji genewskiej o zniesieniu stanu wojennego oraz polecił mu rozpoczęcie rozmów z Warszawą w zakresie nawiązania relacji gospodarczych oraz budowy infrastruktury pocztowej i telegraficznej ${ }^{39}$.

Litwa coraz mocniej odczuwała presje ze strony Związku Radzieckiego, który oczekiwał od niej niezwłocznego uregulowania stosunków dyplomatycznych z Polską. Potwierdzeniem tej tezy jest nota podkomisarza ds. zagranicznych ZSSR Maksima Litwinowa, którą ambasador Litwy w ZSSR Jurgis Baltruszaitis otrzymał 22 listopada $1927 \mathrm{r}$. W piśmie zaznaczono, iż ponaglanie Litwy w tej sprawie wynika z potrzeby możliwie najskuteczniejszego pozbawienia Marszałka pretekstu do zaatakowania Litwy ${ }^{40}$. Oficjalnie Moskwa wspierała politykę zagraniczną Kowna, jednakże należy zwrócić uwagę na budowanie $\mathrm{z}$ jej strony atmosfery strachu i braku zaufania w relacjach polsko-litewskich, czego przykładem może być nota z 27 listopada 1927 r., w której rząd w Moskwie ostrzegał Warszawę o konsekwencjach,

37 Augustinas Voldemaras bei Juzefas Pilsudskis Tautu Sajungoje. Politiku ambicijos ir realybè, Trakai 2010, s. 3.

38 V. Sidzikauskas, op. cit., s. 105.

39 S. Sierpowski, Piłsudski w Genewie. Dyplomatyczne spory o Wilno w roku 1927, Poznań 1990, s. 87.

${ }^{40}$ K. Navickas, TSSR vaidmuo ginant Lietuva nuo imperialistines agresijos 1920-1940 metais, Vilnius 1966, s. 30. 
jakie ta może ponieść w przypadku zaatakowania Litwy. Pomimo eskalacji konfliktu ze strony ZSRR litewski resort spraw zagranicznych nadal tkwił w przekonaniu, iż zażegnanie konfliktu z Polską jest równoznaczne $\mathrm{z}$ bezpowrotną utratą obszaru wileńskiego ${ }^{41}$. Tamtejsze realia polityki zagranicznej wymagały zatem od Voldemarasa utrzymywania równowagi pomiędzy próbą nawiązania stosunków dyplomatycznych z Polską a ich brakiem, tak by nie doprowadzić do ostatecznej utraty Wilna lub skonfliktowania Litwy $\mathrm{z}$ innymi uczestnikami polityki międzynarodowej.

Bardzo pomocny w tym zakresie okazał się dla Litwy szef łotewskiego MSZ Fēlikss Cielēns, pomimo iż Voldemaras dość sceptycznie podchodził do łotewskiego rządu socjaldemokratów z uwagi na wsparcie finansowe, jakie otrzymywały od niego socjaldemokratyczne grupy emigrantów działające w tymże kraju - pleczkatininkus ${ }^{42}$. Grupa ta w dniach 8-9 sierpnia 1927 r. zorganizowała w Taurogach wiec przeciwko rządom Smetony i Voldemarasa. Na podstawie tych wydarzeń litewski premier ostatecznie odmówił pomocy zaoferowanej przez łotewski resort spraw zagranicznych ${ }^{43}$. Z uwagi na odrzucenie łotewskiej propozycji wsparcia Litwy minister Cielēns starał się udzielić pomocy rządowi Voldemarasa za pośrednictwem Republiki Weimarskiej oraz ZSRR. Szef łotewskiego MSZ był przekonany, że zarówno Niemcy, Związek Radziecki, jak i sama Łotwa interesują się zachowaniem integralności terytorialnej Litwy, a co za tym idzie, są skłonne do podjęcia niezbędnych środków, by zapewnić jej bezpieczeństwo.

W przeddzień sesji Rady LN, 6 grudnia 1927 r. odbyło się spotkanie Voldemarasa i Zaleskiego. Wzięli w nim również udział sir Austen Chamberlain, Aristide Briand, Stresemann, Litvinow oraz przewodniczący i sekretarz generalny LN. Podczas tajnego posiedzenia zaproponowano premierowi Litwy przyjęcie bardziej elastycznej linii negocjacyjnej celem załagodzenia konfliktu polsko-litewskiego. Zachodni dyplomaci po rozmowie z Voldemarasem odnieśli się w sposób krytyczny do zakończonych rozmów - zarzucili premierowi Litwy zbyt stanowczą postawę w rozmowach z Polską. Według francuskich dyplomatów nieustępliwość Voldemarasa nie sprzyjała możliwości znalezienia wspólnej płaszczyzny porozumienia: „on tylko udaje, że jest «aniołem pokoju»"44.

7 grudnia 1927 r. na sesji Rady LN premier Litwy został poproszony przez holenderskiego dyplomatę Beelaertsa van Bloklanda o sprecyzowanie swoich celów zawartych w memorandum z 27 października. W skardze Voldemaras wskazał na problem zamykania litewskich szkół w okręgu wileńskim, jak również postulował powołanie komisji międzynarodowej ds. unormowania sytuacji na linii

${ }^{41}$ LCVA, f. 383, Ap. 7, B. 711, L. 48, 1927 m. lapkricio 22 d. telegrama J. Baltrusaiciui i Maskwa.

${ }^{42}$ M. Kuodys, Kovos su antivalstybine propaganda Lietuvos kariuomeneje bruožai 1927-1940 m. karas. Karo archyvas, Kaunas 2014, s. 201.

43 Z. Butkus, Lenkijos agresijos grèsmé Lietuvai ir Latvijos pozicija 1927 m., t. 3, w: Mūsu praeitis, Vilnius 1993, s. 8.

${ }^{44}$ Ibidem, s. 11. 
demarkacyjnej. Szef polskiego MSZ powołując się na art. 11 paktu Ligi, zgłosił sprzeciw, argumentując go bezzasadnością złożonej przez premiera Litwy skargi i wniósł o jej oddalenie. W odpowiedzi na litewską notę minister Zaleski zwrócił się do Rady o pomoc w wynegocjowaniu z Litwą zniesienia stanu wojennego z Polską. Posiedzenie Rady LN nie przyniosło przełomu w relacjach polsko-litewskich ${ }^{45}$.

Kolejne posiedzenie miało miejsce 10 grudnia 1927 r. Ponownie podjęto problematykę normalizacji stosunków polsko-litewskich, zwrócono również uwagę na to, że konflikt ten nie jest zgodny z duchem paktu Ligi. W treści deklaracji zaapelowano do Polski i Litwy, by te niezwłocznie rozpoczęły rokowania celem uregulowania wzajemnych relacji. W rozmowach aktywny udział wziął Marszałek Piłsudski i w najlepiej sobie znany bezkompromisowy sposób - ignorując upomnienia ze strony ministra spraw zagranicznych Francji Brianda - wymusił na Voldemarasie zanegowanie istnienia stanu wojennego między Polską a Litwą ${ }^{46}$. W związku z tym jeszcze tego wieczoru na posiedzeniu LN została przyjęta rezolucja potwierdzająca zniesienie stanu wojennego pomiędzy Litwą a Polską. Rezolucja genewska z 10 grudnia była najważniejszym dokumentem, jaki do tego czasu udało się wynegocjować za pośrednictwem LN w sprawie konfliktu polsko-litewskiego. Dokument konstatował, że oba kraje zobowiązują się do jak najszybszego podjęcia rokowań w oparciu o status quo. W ostatnim akapicie rezolucji zaznaczono, iż Rada po przesądzeniu zasadniczych spraw $\mathrm{w}$ kwestiach zbieżnych $\mathrm{z}$ punktu widzenia stron konfliktu oddaje im samym rozstrzygnięcie sporu ${ }^{47}$. Fragment ten zostanie później wskazany przez Voldemarasa jako podstawa ponownego podniesienia kwestii Wileńszczyzny na forum międzynarodowym. Podpisanie rezolucji genewskiej było przez mocarstwa zachodnie interpretowane jako wielki sukces LN, który zapobiegł w jej mniemaniu wybuchowi konfliktu zbrojnego. Jako największego zwycięzcę rokowań można uznać Marszałka Piłsudskiego, któremu udało się osiągnąć zamierzone cele. W najnowszej histografii litewskiej odkryto nowe fakty dotyczące wydarzeń z 10 grudnia. Wspomnienia zawarte $\mathrm{w}$ promemorium Sidzikauskasa (członka litewskiej delegacji) wskazują na przedwczesną satysfakcję Marszałka Piłsudskiego z osiągnięcia politycznego zwycięstwa. Sidzikauskas twierdził, iż po podpisaniu dokumentu Voldemaras zwrócił się do Piłsudskiego tymi słowami: „to proszę Pana nie jest Pana zwycięstwo, lecz tylko Te Deum pokoju zwycięstwo osiągnięte przeze mnie" 48 .

Późniejsze wydarzenia pokazały jednak, że rezolucja genewska nie rozwiązała konfliktu polsko-litewskiego. W swoich memoriałach dyplomata Sidzikauskas pisał, iż Voldemaras czując nacisk ze strony Marszałka, pierwotnie zgadzał się na

45 S. Baczyński, Dokumenty do pracy Litwa-Polska 1914-1927, Warszawa 1938, teka XI, dok. 40, s. 163.

${ }^{46}$ J. Garlicki, op. cit., s. 484.

${ }^{47}$ Lietuvių-Lenku byla dèl tranzito Nemuno upynu i Kaišiadorių-Lentvario geležinkelio ruožu, D. 1: Sprawa Niemna w stosunkach polsko-litewskich, Kaunas 1931, s. 6.

48 V. Sidzikauskas, op. cit., s. 101. 
ustępstwa, następnie zaś wracał do początkowych postulatów ${ }^{49}$. Gdy premier Litwy przybył z Genewy do Paryża, wystosował krótkie démarche, podając do wiadomości publicznej, iż Rada LN swoją rezolucją z 10 grudnia faktycznie rewokowała uchwałę Rady Ambasadorów z 15 marca 1923 r. Jeden z punktów tego dokumentu odnosił się do zatwierdzenia przebiegu wschodniej granicy II Rzeczypospolitej, w której skład wchodziła również Wileńszczyzna. Oświadczenie Voldemarasa spotkało z negatywną reakcją ze strony ambasadorów Wielkiej Brytanii, Włoch, USA oraz Polski. Jak pisał w tamtym czasie minister Zaleski: „jego exposé nie mogło zatem nie wywołać rozdrażnienia opinii międzynarodowej, krytyki i wrzenia"50.

Co ciekawe, rządy Republiki Weimarskiej i ZSSR odniosły się z dużą aprobatą do podpisanego w Genewie porozumienia, dlatego też dalsze działania Voldemarasa nie uzyskały ich akceptacji ${ }^{51}$. Ambasador Litwy w Berlinie Sidzikauskas pisał w swoim promemorium, iż niemiecki minister spraw zagranicznych Stresemann zapewnił go jednak, że rząd niemiecki jest zdecydowany nadal wspierać rząd w Kownie. Wątpliwości niemieckich przywódców odnośnie do współpracy z Litwą stopniowo zanikały. Berlin wyraził zgodę na samodzielność Voldemarasa w prowadzeniu polityki zagranicznej i odnoszenie się w niej do postulatów innych państw. Sidzikauskas zawarł również w promemorium informację o spotkaniu Stresemanna z komisarzem spraw zagranicznych ZSSR Litwinowem w Genewie, gdzie obaj przywódcy omawiali obecną sytuację stosunków polsko-litewskich. Stresemann oświadczył Litwinowi, iż przedstawiciel Niemiec w Radzie LN został poinstruowany, by sprzeciwiać się jakimkolwiek nowym rozwiązaniom w kwestii Wileńszczyzny, które rozstrzygałyby spór na korzyść Polski, co wskazuje na to, iż Litwa mogła w dalszym ciągu polegać na Stresemannie i Berlinie ${ }^{52}$.

O ile wsparcie ze strony Republiki Weimarskiej było istotne z punktu widzenia litewskiej polityki zagranicznej, o tyle stanowisko ZSRR nie przynosiło znaczących korzyści. Prasa francuska i brytyjska potępiała Związek Radziecki za opublikowane noty, w których Warszawa wyraźnie została ostrzeżona o konsekwencjach płynących ze strony ZSRR $w$ razie agresji na Litwę. Zjawisko nasiliło się na przełomie stycznia i lutego 1928 r., kiedy z Moskwy zaczęły napływać noty ambasady francuskiej informujące o potencjalnych obawach rządu w Moskwie przed agresją marszałka Piłsudskiego. „Lietuva” w tamtym czasie pisała: „możemy wskazać dziesiątki gazet, zaczynając od monarchistów kończąc na radykalnych socjalistach na Zachodzie, którzy negatywnie oceniają radziecką interwencję w sprawy konfliktu polsko-litewskiego. Oczywiste jest, że wsparcie dyplomatyczne Moskwy dla Kowna, negatywnie wpływa na opinię w gremiach francuskich oraz brytyjskim społeczeństwie, jak również wśród polityków”. Prawdopodobnie należy zgodzić

\footnotetext{
49 Ibidem, s. 107.

50 Ibidem, s. 108.

51 Ibidem, s. 108.

52 „Voruta” (2003), bal. 6, nr 7 (505), s. 4-5.
} 
się z tezą Algisa Kasperavičiusa, że Związek Radziecki nie zamierzał bronić swojego partnera politycznego, ale dążył do neutralizacji polskiej polityki w regionie wschodnim, która była dla Moskwy niekorzystna, a czasem nawet i wroga ${ }^{53}$.

Należy w tym miejscu zapytać o zasadniczą rolę rezolucji genewskiej z 10 grudnia. Według polskich dyplomatów nie wzięła ona pod uwagę sprawy Wileńszczyzny, ponieważ normatywnie moc prawną miała w tym zakresie uchwała Rady Ambasadorów z 15 marca 1923 r., która de facto nie została zaimplementowana przez rząd litewski. Badaczka polityki zagranicznej Litwy Regina Žepkaité, zaznaczyła, iż rezolucja genewska była największą porażką dyplomatyczną poniesioną przez Voldemarasa. LN nadal mogła interweniować w zakresie stosunków polsko-litewskich, ponadto rząd $w$ Kownie faktycznie zgodził się na prowadzenie dalszych rokowań $\mathrm{z}$ Polską $\mathrm{w}$ oparciu o status $q u o^{54}$. Litewski historyk Liudas Truska zaś kontrargumentował, że Voldemaras w Genewie wygrał z marszałkiem Piłsudskim. Według badacza, opierającego się na opinii jednego z najwybitniejszych prawników międzywojennej Litwy Michała Romera, rezolucja genewska zawiera klauzulę umożliwiającą prowadzenie dalszej dyskusji w kwestii przynależności Wilna i jego okolic ${ }^{55}$.

Najnowsze badania potwierdzają, iż dyplomacja Voldemarasa, pomimo ustępstw, nie przegrała negocjacji. Premier Litwy podpisując porozumienie, pozostawił litewskiej dyplomacji furtkę do podjęcia dalszych rozmów w kwestii Wileńszczyzny. Mimo iż historia zapomniała o roli, jaką odegrał Voldemaras w zakresie tworzenia omówionego dokumentu, jego wkład był zasadniczy ${ }^{56}$.

Premier Litwy wrócił do kraju jako triumfator. Będąc już w Kownie, najpierw udał się do kancelarii prezydenta, gdzie odbył spotkanie ze Smetoną. Prezydent Litwy nie krył swojego zadowolenia $\mathrm{z}$ sukcesów odniesionych podczaj sesji genewskiej przez Voldemarasa, o czym świadczyć może jego wypowiedź: „Co my byś zrobili bez P. Profesora Voldemarasa? Kto, jak nie on potrafiłby tak mężnie i kompetentnie obronić interesy Litwy w Genewie?" ${ }^{7} .11$ lutego 1928 r., w dniu obchodów odzyskania przez Litwę niepodległości, Voldemaras został odznaczony za swoje zasługi Orderem Wielkiego Księcia Giedymina.

Francja i Wielka Brytania założyły wspólnie, iż rezolucja genewska z 10 grudnia jest preludium do wznowienia rokowań pomiędzy Polską a Litwą. Przed wyjazdem Voldemarasa z Genewy minister Zaleski zaprosił go do Rygi, gdzie planowano prowadzić dalsze rozmowy w zakresie normalizacji stosunków polsko-litewskich. Premier Litwy odrzucił jednak otrzymaną propozycję, argumentując swoją decyzję obecnością w miejscu obrad posła Juliusza Łukasiewicza, ambasadora RP w Rydze, który jawnie prowadził politykę antylitewską, co nie spotkało się z akceptacją ze

53 A. Kasperavičius, Naujausiujų laiku istorija, Vilnius 1993, s. 46-47.

54 R. Žepkaité, Diplomatija imperializmo tarnyboje, Vilnius 1980, s. 205.

55 L. Truska, Antanas Smetona ir jo laikai, Vilnius 1996, s. 186.

56 G. Vilkelis, Lietuvos ir Lenkijos santykiai Tautu Sajungoje, Vilnius 2006, s. 14.

57 V. Gustainis, Nuo Griškabūdžio iki Paryžiaus, Kaunas 1991, s. 78. 
strony rządu w Kownie ${ }^{58}$. Voldemaras oświadczył ministrowi Zaleskiemu: „w żaden sposób p. ministrze nie widzę możliwości prowadzenia rokowań w obecności ambasadora RP p. Łukasiewicza" 59 .

W rzeczywistości Voldemaras unikał wznowienia rokowań z polską delegacją. Istniały ku temu cztery główne powody. Dyplomata Klimas - litewski wysłannik pełniący obowiązki przy ambasadzie francuskiej - wskazał na dwa z nich: po pierwsze, celem Voldemarasa było sprowadzenie wszystkich kwestii poddanych negocjacjom do sprawy Wileńszczyzny, co stanowiłoby punkt wyjścia dalszych dyskusji; po drugie, Litwa próbowała uzyskać od strony polskiej $10 \mathrm{mln}$ dolarów odszkodowania za zorganizowaną przez Żeligowskiego akcję w Wilnie ${ }^{60}$. Trzecią przesłankę przywołała Žepkaité, która zauważyła, iż cała uwaga rządu w Kownie była skoncentrowana na zawarciu polityczno-gospodarczego paktu z Republiką Weimarską. Kolejny pakiet pomocy finansowej od Reichsbanku był niezbędny do prowadzenia dalszych działań dywersyjnych przeciwko Polsce. Jako czwarty argument przywołuje się powstanie na początku kwietnia 1927 r. Litewskiej Partii Ludowej z eksprezydentem Kazysem Griniusem na czele oraz problemy związane z Partią Chrześcijańskich Demokratów, usuniętą z koalicji rządzącej 20 kwietnia 1927 r. Formacja ta stawiała opór wobec każdej z form prowadzenia rozmów z Warszawą ${ }^{61}$.

\section{Kolejny zastój w stosunkach polsko-litewskich}

Strona polska nieprzerwanie wykazywała chęci wznowienia i uregulowania stosunków z Kownem. Jak wynika ze ściśle tajnej korespondencji z 12 maja 1928 r. między Balutisem - dyrektorem Departamentu Politycznego MSZ (odpowiadającym za politykę zachodnią) a Tadeuszem Hołówką, naczelnikiem wydziału wschodniego w Departamencie Politycznym MSZ, Warszawa najbardziej obawiała się wzmocnienia wpływów politycznych Rzeszy Niemieckiej na rząd w Kownie ${ }^{62}$. Balutis w swoim promemorium pisał: „priorytetowym celem Warszawy było zamknięcie Kowna w politycznym trójkącie" ${ }^{63}$ :

$\sum$ Rzesza $>$ Polska $>$ Litwa $>$

Wiedząc o tych planach, Voldemaras nieprzypadkowo dążył do nawiązania przez Litwę bliższych stosunków z Berlinem, nawet kosztem poczynienia ustępstw podczas negocjacji. Na przełomie stycznia i lutego rozpoczęto zintensyfikowaną

58 Z. Butkus, op. cit., s. 13.

59 Ibidem.

${ }^{60}$ P. Klimas, Lietuvos diplomatineje tarnyboje 1919-1940 m., Vilnius 1991, s. 77.

${ }^{61}$ R. Žepkaité, Diplomatija imperializmo tarnyboje..., s. 213.

${ }^{62}$ B.K. Balutis, Jo gyvenimas ir darbai, Michigan 1951, s. 98-99.

${ }^{63}$ Ibidem. 
wymianę not dyplomatycznych między Zaleskim i Voldemarasem. Kontakt z rządem litewskim został zainicjowany przez szefa polskiego MSZ, który 8 stycznia 1928 r. wystosował notę do Voldemarasa z propozycją spotkania i rozpoczęcia 31 stycznia ponownych negocjacji. Według badacza stosunków polsko-litewskich Stanisława Gorzuchowskiego w protokole obrad miały zostać zawarte takie sprawy, jak powrót do omówienia stosunków gospodarczych pomiędzy sąsiadami, problem rozbudowania infrastruktury pocztowej i telegraficznej, tranzytu oraz sprawy ruchu kolejowego ${ }^{64}$. Po wysunięciu propozycji przez polskiego ministra pomiędzy politykami rozpoczęła się długa wymiana korespondencji o charakterze konfrontacyjnym. Voldemaras w odpowiedzi na wystosowane przez Zaleskiego noty z 8 stycznia i 9 lutego zarzucił rządowi polskiemu, że przyczyną, dla której Litwa nie chce zacząć ponownych rozmów, jest utrzymywanie na terenie Rzeczypospolitej Polskiej oddziałów separatystyczno-emigranckich, które zagrażają integralności terytorialnej Litwy. Szef delegacji litewskiej zaproponował powołanie mieszanej komisji ds. zbadania sprawy separatystów przebywających na terenie RP oraz utworzenia strefy neutralnej ${ }^{65}$, minister Zaleski zaś zaproponował stronie litewskiej zawarcie konwencji o nieagresji.

Premier Litwy ostatecznie zdecydował o wznowieniu rozmów z Polską. Niebagatelny wpływ na decyzję premiera miało otoczenie międzynarodowe, a w szczególności LN, rząd Niemiec oraz ambasador Puaux. Wznowienie rozmów miało miejsce 30 marca 1928 r. w Królewcu. Strona polska była reprezentowana przez ministra Zaleskiego oraz jego zastępcę Hołówkę ${ }^{66}$. Voldemaras rozpoczął negocjacje od poruszenia kwestii Wileńszczyzny oraz zreferowania historii bezprawnego działania Polaków w stosunku do Litwy, co wprowadziło wśród zebranych nerwową atmosferę. Po wymianie poglądów na temat wysuwanych przez Voldemarasa oskarżeń, w kolejnym dniu rozmów - 31 marca - delegacja polska wystosowała pismo, w którym zaproponowała stworzenie programu rozwoju gospodarczego dla obu stron. W jego treści miały się znaleźć takie zagadnienia, jak: regulacja przekraczania granicy, regulacja łączności pocztowej i telegraficznej, komunikacji kolejowej oraz tranzytu ${ }^{67}$. Na preliminarnym posiedzeniu 3 kwietnia delegacja polska wystąpiła z propozycją utworzenia w tym celu trzech komisji: politycznej, ekonomicznej oraz prawnej, które miały kontynuować pracę nad proponowanym projektem gospodarczym. Voldemaras w odpowiedzi wykonał niespodziewany manewr - zażądał od rządu polskiego reparacji w wysokości 10 mln dolarów. W odpowiedzi na żądania szefa delegacji litewskiej minister Zaleski oświadczył na piśmie, że rezerwuje sobie prawo wystąpienia z wypłaceniem stronie polskiej reparacji za straty, jakich doświadczyła ona na skutek współdziałania rządu

${ }^{64}$ S. Gorzuchowski, Granica polsko-litewska w terenie, Warszawa 1928, s. 5.

${ }^{65}$ D. d. Koenisgsberg, t. 1, dok. 2, s. 13-16.

66 „Lietuvos žinios” (28 III 1928), nr 43.

67 D. d. Koenisgsberg, s. 12. 
litewskiego z Moskwą podczas wojny polsko-radzieckiej w $1920 \mathrm{r} .{ }^{68}$ Nie znajdując trafnych kontrargumentów, Voldemaras zaakceptował propozycję szefa delegacji polskiej, w związku z czym zakończono pierwszy etap negocjacji w Królewcu ${ }^{69}$. Minister Zaleski był głęboko przekonany, iż szef delegacji litewskiej nie dokona błyskawicznego manewru, który mógłby zerwać rokowania, o czym wspominał w wysłanej do polskiego MSZ depeszy ${ }^{70}$.

5 kwietnia 1928 r. na posiedzeniu 49. sesji Rady LN minister spraw zagranicznych Wielkiej Brytanii Chamberlain wystąpił z propozycją unormowania stosunków dyplomatycznych między Litwą a Polską poprzez ratyfikację rezolucji genewskiej. Treść deklaracji miała wydźwięk optymistyczny - oczekiwano w niej, iż do kolejnego posiedzenia LN obie strony poczynią postępy w zakresie poprawy wzajemnych stosunków dyplomatycznych. Rezolucja nie nabrała mocy prawnej $\mathrm{z}$ uwagi na fakt, iż Voldemaras głosował przeciwko jej wdrożeniu, niemniej dyplomaci Wielkiej Brytanii próbowali wywrzeć nacisk na Litwę poprzez Republiką Weimarską, co wskazuje na rosnące znaczenie Niemiec na arenie międzynarodowej. Chamberlain planował wcielić - przy współpracy z Polską - Litwę w blok antyrosyjski, w którym miały znaleźć się również Polska, Rumunia oraz kraje bałtyckie. Celem premiera Wielkiej Brytanii była izolacja ekonomiczno-polityczna Rosji w regionie Europy Środkowo-Wschodniej, dzięki której miałoby dojść do zmiany polityki zagranicznej ZSSR względem Brytyjczyków ${ }^{71}$.

Po posiedzeniu Rady LN, 5 kwietnia 1928 r. Voldemaras podczas tajnego spotkania z przedstawicielem niemieckiego MSZ został zobligowany do wznowienia negocjacji z delegacją polską w ramach „programu minimum”, tj. poczynienia ustaleń w zakresie ruchu granicznego, łączności pocztowej i telegraficznej, komunikacji kolejowej oraz tranzytu ${ }^{72}$.

Wracając do prac w komisjach, Voldemaras sprawnie sprowadził negocjacje do sprawy Wileńszczyzny, co stanowiło również punkt wyjścia podczas dalszych rozmów ${ }^{73}$. Podjęte 7 maja 1928 r. prace w komisjach wskazywały na utrzymującą się tendencję po stronie litewskiej do zrywania wszystkich punktów ustalonych pierwotnie przez obie strony delegacji. Jeżeli chodzi o ważne ustalenia poczynione podczas prac $\mathrm{w}$ komisjach, należy zwrócić uwagę na Komisję ds. Bezpieczeństwa i Uregulowania Roszczeń z Przeszłości. 8 maja strona polska z przewodniczącym Hołówką na czele złożyła na ręce przewodniczącego Komisji ds. Bezpieczeństwa Balutisa projekt traktatu o nieagresji wraz z paktem arbitrażowo-koncyliacyjnym ${ }^{74}$.

68 Ibidem, dok. 18, s. 41.

${ }^{69}$ AAN, MSZ, t. 6107 , s. 52.

70 A. Zaleski, Przemowy i deklaracje, t. 1, Warszawa 1929, s. 134.

${ }^{71}$ LCVA, f. 671, Ap. 1, B. 5, L. 2.

72 R. Skipitis, Nepriklausoma Lietuva. Atsiminimai, Chicago 1967, s. 477.

73 P. Łossowski, Stosunki polsko-litewskie 1921-1939, Warszawa 1997, s. 161-162.

${ }^{74}$ D. d. Koenisgsberg, t. 2, dok. 8-10, s. 39-49. 
Pomimo dobrej woli i pokojowych zamiarów delegacji polskiej strona litewska 12 maja 1928 r. wystosowała dokument, w którym odrzuciła zaproponowany przez Polskę projekt, jednocześnie twierdząc, że nie widzi możliwości prowadzenia dalszych rokowań w tym zakresie ${ }^{75}$. Minister Zaleski w depeszy z 15 maja 1928 r. do ambasadora w Londynie Konstantego Skirmunta pisał: „celową strategia Voldemarasa i litewskich komisji jest zademonstrowanie, że nawet prowizoryczne modus vivendi, między stronami konfliktu jest niemożliwe do uzgodnienia bez uprzedniego uregulowania kwestii Wilna"76.

Na posiedzeniu 50. sesji Rady LN 6 czerwca 1928 r. Chamberlain, Joseph Paul-Boncour i Beelaerts van Blokland dokonali oceny postępów prac w komisjach. Wnikliwa analiza dostępnych materiałów wskazała na rozczarowujący brak progresu w prowadzonych rokowaniach. Osobą odpowiedzialną za brak postępów był niewątpliwie Voldemaras, który nie zgadzał się na żadne zaproponowane porozumienie, argumentując swoją decyzję niezmiennym przebywaniem na granicy polsko-litewskiej oddziałów separatystów podejrzewanych o współpracę z Warszawą ${ }^{77}$. Chamberlain po posiedzeniu Rady LN 6 czerwca zaprosił Voldemarasa do Londynu. Wizytę zaplanowano na 18 maja 1928 r. Nieugięta postawa litewskiego premiera umocniła pozycję ministra Zaleskiego na arenie międzynarodowej, który dzięki swojej elastyczności i ugodowości w negocjacjach z Litwą zjednał sobie dyplomatów francuskich i brytyjskich ${ }^{78}$. Jak raportował 27 września 1929 r. pełniący funkcję chargé d'affaires w Londynie Jan Wszelaki, taktyka Voldemarasa oddała Polsce przysługę, jeżeli chodzi o relacje dyplomatyczne z Brytyjczykami ${ }^{79}$.

18 maja 1928 r. Voldemaras przybył do Londynu, gdzie wziął udział w rozmowach z ministrem spraw zagranicznych Wielkiej Brytanii. Zasadniczym celem spotkania było omawianie problematyki stosunków polsko-litewskich w kontekście prac w komisjach. W Foreign Office Voldemaras został poinstruowany przez Chamberlaina o konieczności zniesienia obstrukcyjnej polityki wobec Polski. Tymczasem podczas wizyty Voldemarasa w Londynie, 25 maja 1928 r. „Lietuvos žinios” opublikował nową Konstytucję Republiki Litewskiej, w której w paragrafie 5 zapisano, iż Litwa jest suwerennym państwem ze stolicą w Wilnie. Pod koniec wizyty litewskiego premiera w Londynie Chamberlain wyraził pogląd, iż gabinet Voldemarasa świadomie ogłosił nową konstytucję $\mathrm{w}$ momencie, gdy jego premier przebywał $\mathrm{z}$ wizytą w Wielkiej Brytanii, aby udowodnić LN i Polsce, iż rząd w Kownie uchwalił dokument przy aprobacie rządu brytyjskiego, z czym Voldemaras się nie zgadzał ${ }^{80}$.

28 czerwca 1928 r. Komisja ds. Bezpieczeństwa i Uregulowania Roszczeń z Przeszłości rozpoczęła drugi etap prac. Balutis, poinstruowany przez Voldemarasa,

\footnotetext{
75 Ibidem, dok. 11, s. 58.

76 AAN, Ambasada w Londynie, t. 351, s. 6-8.

77 D. d. Koenisgsberg, dok. 3, s. 13.

78 MAE, Pologne, V. 9, Note sur Zaleski, 22 VIII 1928, s. 198.

79 AAN, Ambasada w Londynie, t. 136, s. 102.

${ }^{80}$ V. Sidzikauskas, op. cit., s. 108.
} 
nie dopuszczał do przyjęcia żadnych ustaleń, argumentując to brakiem uregulowania kwestii przynależności Wilna. Według Balutisa obszar pomiędzy linią wyznaczoną w pakcie litewsko-radzieckim z 12 lipca 1920 r. a linią paktu Rady LN z 3 lutego 1923 r. nie pokrywał się, nie było również porozumienia między Polską a Litwą w tej sprawie. Ostatecznie komisja litewska zajęła się rozstrzygnięciem kwestii przynależności Wilna, tym samym kwestionując integralność terytorialną Rzeczypospolitej Polski ${ }^{81}$.

Tymczasem podobna atmosfera panowała w Komisji Ekonomii, Komunikacji i Tranzytu, gdzie współprzewodniczący Dovas Zaunius, poinstruowany przez Voldemarasa, niejednokrotnie naruszał konwencję międzynarodową obligującą Litwę do otwarcia tranzytu z Polską. Przykładowo 21 maja 1928 r. na posiedzeniu komisji kategorycznie sprzeciwił się zawarciu układu o bezpośrednim połączeniu z Polską przez obszar sporny - Wileńszczyznę $e^{82}$. Zaunius odrzucał również polskie projekty dotyczące stosunków handlowych między Polską a Litwą, ponieważ też odnosiły się do obszaru spornego - Wilna, z którego Litwa nie życzyła sobie importować produktów ${ }^{83}$.

21 maja w Berlinie rozpoczęto prace w Komisji ds. Prawa i Ruchu Lokalnego, której przewodniczyli Sidzikauskas i Adam Tarnowski. Podobnie jak w przypadku prac prowadzonych przez pozostałe komisje, nie doszło do podpisania żadnych porozumień, a obrady dotyczyły kwestii rewindykacji terytorialnej i ustalenia przynależności Wilna ${ }^{84}$.

Jak widać z powyższych faktów historycznych, prace komisji nie przyniosły przełomu w stosunkach polsko-litewskich. 7 listopada w Królewcu Komisja ds. Prawa i Ruchu Lokalnego doprowadziła do podpisania porozumienia dotyczącego małego ruchu granicznego w basenie Morza Bałtyckiego, jednak znaczenie tego dokumentu było niewielkie. W kwestii linii demarkacyjnej strony jedynie uzgodniły zmianę nazwy na „linię administracyjną" ${ }^{2}$.

6 września 1928 r., na kolejnej sesji Rady LN, van Blokland przedstawił raport dotyczący postępów w zakresie stosunków polsko-litewskich. Holender w zaprezentowanym dokumencie przyznał, że ocenia wyniki prac komisji jako bardzo słabe. Premier Litwy odniósł się do tego raportu, oskarżając stronę polską o niedotrzymanie niektórych terminów oddania projektów oraz zwłokę w ustaleniu trzeciego posiedzenie plenarnego $\mathrm{w}$ Królewcu, zdejmując tym samym $\mathrm{z}$ Litwy część odpowiedzialności za brak efektów prac komisji ${ }^{86}$.

Trzecie, ostatnie posiedzenie w Królewcu odbyło się 3 listopada 1928 r. Przeanalizowane zostały wyniki prac $\mathrm{w}$ komisjach. W protokole plenarnym

${ }^{81}$ D. d. Koenigsberg, dok. 12, s. 58-61.

82 Ibidem, dok. 19, s. 81-85.

83 Ibidem, dok. 23, s. 98-119.

${ }^{84}$ Ibidem, dok. 25, s. 123-124.

85 Lietuvių-Lenkų byla dèl tranzito..., s. 112.

${ }^{86}$ D. d. Koenigsberg, t. 3, dok. 13, s. 19-42. 
stwierdzono, iż w każdej kategorii brakuje pozytywnych rezultatów ${ }^{87}$. Brak postępów w zakresie unormowania stosunków polsko-litewskich był głównym tematem posiedzenia Rady LN w Locarno w grudniu 1928 r. 14 grudnia na plenarnym spotkaniu Rady zostały przedłożone dwie rezolucje, które poparł również Voldemaras. Sidzikauskas w swoim promemorium skomentował to wydarzenie, określając je jako ostatnie emploi Voldemarasa na arenie międzynarodowej, gdyż nie było mu już dane więcej reprezentować Litwy za granicą ${ }^{88}$.

Według Žepkaité wystąpienie Voldemarasa w Królewcu miało na celu zaburzyć spokój prowadzonych ze stroną polską rozmów, a w konsekwencji doprowadzić do zerwania rokowań w oparciu o modus vivendi. Jest rzeczą oczywistą, iż przyjęta przez Voldemarasa taktyka blokowania wyjścia $\mathrm{z}$ dotychczasowego impasu została również zalecona pozostałym litewskim członkom komisji. Gra polityczna Voldemarasa była skuteczna, jeżeli chodzi o osiągnięcie obranego przez niego celu, jednak ceną za jej prowadzenie okazał się niekorzystny odbiór polityka $\mathrm{w}$ gremiach dyplomacji zarówno międzynarodowej, jak i polskiej ${ }^{89}$. Znamienne były wówczas słowa Hołówki, który oświadczył po konferencji w Królewcu: „Szef dyplomacji litewskiej celowo wyprowadzał nas z równowagi, można było odnieść wrażenie, że Litwini swoją sarkastyczną postawą szydzili z nas przed całą LN"

Tymczasem rząd w Warszawie próbował dociec, jakimi motywami i przesłankami kierował się Voldemaras w swojej polityce zagranicznej ${ }^{91}$.

\section{Renegocjacje polityczne oraz ekonomiczne z Republiką Weimarską}

Od początku istnienia niepodległej Litwy utrzymanie dobrych stosunków z Republiką Weimarską na tle gospodarczym stanowiło priorytetowy cel Taryby. Okazało się, iż nie wszystkie konwencje zawarte z Berlinem były korzystne dla państwa litewskiego, ponieważ większość z nich od strony prawnej dotyczyła ochrony weimarskich interesów, jednakże umowy sprzyjające stronie niemieckiej zostały wynagrodzone Litwinom w formie pomocy gospodarczej i politycznej świadczonej im przez Republikę Weimarską. Podczas rokowań rząd litewski starał się zapewnić sobie jak największy wolumen eksportu na rynek niemiecki, tym samym uzyskać pozwolenie ze strony Berlina na tranzyt litewskich towarów do innych krajów. Niemcy były ważnym partnerem dla Litwy pod względem gospodarczym, co pokazują dane makroekonomiczne z 1925 r.: litewski eksport do Republiki Weimarskiej wynosił $51 \%$, a import z niej - 56,61\% całej wymiany handlowej, co wskazuje na

${ }^{87}$ Ibidem, dok. 16, s. 56-61.

88 V. Sidzikauskas, op. cit., s. 108-109.

89 R. Žepkaité, Diplomatija imperializmo tarnyboje..., s. 218.

90 LCVA, f. 383, Ap. 7, B. 774, L. 94.

91 AAN, MSZ, t. 6076, s. 62. 
to, iż Niemcy miały podstawy do silnego oddziaływania na Litwę pod względem politycznym ${ }^{92}$. Rząd w Kownie był świadomy oczekiwań Berlina wobec obszaru kłajpedzkiego oraz traktatu $\mathrm{z}$ Locarno ${ }^{93}$, który otworzył Niemcom drogę do rewizji granicy z Polską i Litwą. Rozpowszechniała się myśl o „Wschodnim Locarno”, tj. traktacie, jaki Voldemaras miał w planach zawrzeć z Berlinem. Założono, że dokument zagwarantuje bezpieczeństwo zachodniej granicy litewskiej. W dalszej perspektywie traktat miał posłużyć jako ważny instrument $\mathrm{w}$ walce z Polską ${ }^{94}$.

\section{Kłajpeda jako dylemat konfliktu i kooperacji w stosunkach litewsko-niemieckich}

Największym dylematem Litwy w stosunkach z Republiką Weimarską była kwestia obszaru Kłajpedy. Chciano nakłonić Berlin do odmowy zgłaszania roszczeń terytorialnych $\mathrm{w}$ stosunku do tego obszaru. W tym celu rząd kowieński domagał się zawarcia porozumienia z Berlinem. Jeszcze w lipcu 1926 r. oddelegowany przez premiera Sleževičiusa przedstawiciel Litwy w Berlinie, Sidzikauskas został poinformowany przez rząd niemiecki, iż MSZ Republiki Weimarskiej oficjalnie deklaruje chęć nawiązania dobrych stosunków politycznych i ekonomicznych $\mathrm{z}$ państwem litewskim.

19 grudnia 1926 r. Voldemaras przejmując stanowisko premiera, nie skupiał dużej uwagi na prowadzeniu rokowań z Republiką Weimarską w tym zakresie. Był on jednak przekonany, iż zawarcie umowy w sprawie przyznania Litwie de iure obszaru Kłajpedy wraz z portem pozwoli zawrzeć w dalszej perspektywie korzystniejszą umową handlową oraz poprawi pozycję polityczną Litwy na arenie międzynarodowej przed rozpoczęciem rokowań z Polską. W tym kierunku w latach 1927-1928 Voldemaras rozpoczął pertraktacje z Berlinem ${ }^{95}$.

Pierwsza tura negocjacji odbyła się w dniach 19-25 lipca 1928 r. w Berlinie, gdzie obie strony wstępnie omówiły kwestie zarówno ekonomiczne, jak i polityczne. Godne uwagi jest to, iż zasiadając do okrągłego stołu ze Stresemannem, Voldemaras w drugiej części obrad, tj. w dniach 4-5 października, przedłożył niemieckiemu ministrowi litewski plan gospodarczy. W jego treści zawarto takie kwestie, jak: sprawa arbitrażu, granicy zachodniej z Niemcami czy rybołówstwo na

92 B. Daščioras, Lietuvos ir Vokietijos ekonominiu santykių, susijusiu su Klaipédos krašto perèjimu Lietuvos suverenitetan, reguliavimas 1923-1929 metais, t. 23, Vilnius 1974, s. 76-82.

93 Traktat z Locarno został podpisany 16 października 1925 r. przez Niemcy, Francję, Wielką Brytanię, Belgię i Włochy. Zakładał gwarancję nienaruszalności granicy niemiecko-belgijskiej oraz niemiecko-francuskiej. Ostatecznie wysiłki polskiego ministra spraw zagranicznych Aleksandra Skrzyńskiego, aby państwa Ententy zagwarantowały przebieg granicy polsko-niemieckiej, nie zostały wzięte pod uwagę, co wkrótce otworzyło Niemcom drogę do rewindykacji terytorium na granicy z Polską.

${ }_{94}$ B. Daščioras, op. cit., t. 23, s. 107.

${ }^{95}$ Lietuvių-Lenku byla dèl tranzito..., s. 12. 
Morzu Bałtyckim. Drugi projekt zaproponowany przez Litwę dotyczył ruchu przygranicznego. Według Voldemarasa projekty te uzyskały akceptację Stresemanna ${ }^{96}$.

Tuż przed kolejną turą negocjacji, zaplanowaną na 25 stycznia 1928 r., $\mathrm{w}$ połowie miesiąca $\mathrm{w}$ prasie niemieckiej zostały opublikowane przez Richarda von Coudenhove-Kalergi plany Bundestagu, które wzbudzały duże obawy rządu litewskiego. Polityk ten ujawniał najświeższe założenia niemieckiej polityki zagranicznej, w których m.in. wyszczególniono chęć złagodzenia konfliktu we wschodniej części Europy. Dokument nosił tytuł „Plan pacyfikacji Wschodu”. Co ciekawe, analogiczny plan zaprezentował podczas paryskiej konferencji pokojowej w marcu 1924 r. włoski poseł w Londynie Giacomi De Martino. Koncepcje tych dwóch autorów zawierały propozycję oddania korytarza polskiego (zwanego również pomorskim lub gdańskim) Republice Weimarskiej. Do korytarza należałoby Wolne Miasto Gdańsk, ponadto Polska miałaby uzyskać dostęp do morza przez Litwę oraz Kłajpedę. Analiza ściśle tajnego listu napisanego przez litewskiego ambasadora w Berlinie do premiera Voldemarasa wskazuje na dużą powagę tych zamiarów:

Kowno Poufne

Sz.P. Premierze

Zbliżając się do litewsko-niemieckich negocjacji gospodarczych, jestem zobowiązany przedstawić Sz. P. kilka przesłanek w zakresie litewskiej polityki zagranicznej oraz wynikających z nich kwestii taktycznych.

W litewskiej jak i w weimarskiej prasie zostały opublikowane plany grafa Coudanhove-Callergi, w wynik, których szerzy się niepokój w środowisku politycznym jak i w prasie litewskiej. Deklaracja grafa, która zakłada pokojowe rozwiązywanie problemów we wschodniej części Europy zyskuje coraz większą popularność i aprobatę w weimarskiej prasie; centralny punkt planu zawiera się w myśli, iż należy wrócić Niemcom Korytarz Pomorski z Dancingiem oraz zapewnić Polsce dostęp do Morza Bałtyckiego przez Litwę. Rozmawiałem z nim osobiście w Berlinie i z tej rozmowy wynika, iż uważa on Litwę za prowincję Polski. Jednakże osobiście oświadczyłem mu, iż Litwa zdecydowanie w żadne związki federacyjne lub konfederacyjne z Polską nie wejdzie.

J.B. ${ }^{97}$

Wszelkie sprawy związane $\mathrm{z}$ rozstrzygnięciem przynależności terytorium Kłajpedy Smetona powierzył Voldemarasowi. 25 stycznia 1928 r. premier wraz ze swoim asystentem, dyrektorem departamentu gospodarki litewskiej Zauniusem udał się do Berlina w celu prowadzenia rokowań z kanclerzem i ministrem spraw zagranicznych Republiki Weimarskiej Stresemannem. Wziął w nich również udział urzędnik litewskiej służby dyplomatycznej Sidzikauskas, który w swoim pamiętniku odnotował spotkanie z kanclerzem, pisząc: „nasze uzasadnienia dot. Kłajpedy przekonały dr. Stresemanna, i przyjął on zaproponowaną przez nas notę.

96 B. Daščioras, op. cit., t. 26, s. 98.

97 LCVA, f. 671, Ap. 1, B. 5, L. 50. 
Aprobatę uzyskaliśmy od Stresemanna dzięki jego osobistym przyjacielskim relacjom z Voldemarasem" 98 .

W kwestiach związanych z unifikowaniem granic między państwami-stronami konwencja nie zastrzegała żadnej stabilizacji, jak również nie zostały wdrożone ustalenia dotyczące wspólnej granicy (mające obowiązywać do odwołania), jednakże podpisanie konwencji między Voldemarasem a Stresemannem można uznać jako jeden z największych sukcesów w karierze politycznej premiera.

W dniach 25-29 stycznia 1928 r. Voldemaras prowadził rokowania ze Stresemannem w sprawie nowej umowy handlowej między państwami-stronami. Traktat dotyczył sprawy importu litewskich produktów rolnych do Republiki Weimarskiej. Jak podawał do wiadomości publicznej organ „Lietuvos ūkis”, w negocjacjach ze Stresemannem Voldemaras ustalił nowy kierunek działania, głównym celem spotkania miało być natomiast omówienie spraw odnoszących się do importu litewskich produktów rolnych do Niemiec. Szeroko omówione zostały kwestie związane z zezwoleniem na import bydła i produktów mięsnych do Niemiec oraz z możliwością obniżenia cła na te produkty ${ }^{99}$. Arcytrudne okazały się dla Voldemarasa berlińskie negocjacje ze Stresemannem w sprawie ustalenia granic między stronami. Zasadniczy spór dotyczył ustalenia granicy od Smolników w obrębie historycznej Małej Litwy do Zalewu Kurońskiego przez Neryngę i Morze Bałtyckie. Berlin wymagał od strony litewskiej zgody na umieszczenie klauzuli, iż owa granica jest ustalona i ratyfikowana $\mathrm{w}$ art. 99 umowy wersalskiej. Pominięcie w traktacie klauzuli oznaczałoby, iż Kłajpeda de iure to odrębne od Republiki Weimarskiej terytorium, przez co Berlin byłby zmuszony odstąpić od dalszych roszczeń. Inny powód dążenia przez delegację litewską do pominięcia $w$ traktacie tejże klauzuli stanowiło pośrednie umocnienie pozycji negocjacyjnej Polski w rozmowach z Litwą $\mathrm{w}$ zakresie ustalenia wspólnej granicy ${ }^{100}$. Voldemaras wyjawił Stresemannowi, iż Warszawa zapewne podniesie temat opierania się Litwy w rozmowach z Republiką Weimarską $w$ dokumentach sporządzonych przez zachodnie mocarstwa, gdzie $\mathrm{w}$ rokowaniach $\mathrm{z}$ Polską odrzucała dotychczas wszystkie propozycje i przyjęte rezolucje. Silna pozycja negocjacyjna Berlina zmusiła jednak delegację litewską do wyrażenia zgody na omówione kwestie ${ }^{101}$.

30 stycznia 1928 r. została podpisana i ratyfikowana konwencja dotycząca handlu i prawa morskiego na terytorium Kłajpedy. Była to ostatnia umowa podpisana przez Voldemarasa jako premiera i ministra spraw zagranicznych Litwy. Pomimo iż klauzula stawiała we wzajemnych stosunkach Litwę na gorszej pozycji względem Republiki Weimarskiej, można ocenić ten układ jako obopólnie korzystny, ponieważ skutki konwencji pozwoliły ożywić handel i tranzyt przez

\footnotetext{
98 A. Eidintas, Antanas Smetona ir jo aplinka, Vilnius 2012, s. 107-129.

99 „Lietuvos ūkis” (27 I 1928), nr 2, s. 68.

100 V. Sidzikauskas, op. cit., s. 81.

101 A. Voldemaras, op. cit., s. 109.
} 
Kłajpedę. Do 1928 r. eksport do Republiki Weimarskiej był mniejszy niż import, jednakże w latach 1928-1930 odnotowano dodatnie saldo wymiany handlowej spadł import, wzrósł zaś eksport towarów litewskich do Republiki Weimarskiej. Przez ten czas Litwa wygenerowała zysk na poziomie 96,5 mln litów. Niezależnie od sukcesów w prowadzonych przez Voldemarasa negocjacjach gospodarczych, konwencja stwarzała możliwość wywierania wpływu politycznego na Kłajpedę przez Republikę Weimarską. Od 1928 r. Kłajpeda stała się najbogatszym miastem w kraju oraz głównym litewskim ośrodkiem handlu zagranicznego ${ }^{102}$.

\section{Podsumowanie}

Polityka zagraniczna prowadzona przez Voldemarasa z czasem wpłynęła negatywnie na postrzeganie Litwy na arenie międzynarodowej, doprowadzając do jej izolacji. Państwo to nie cieszyło się zbyt dużą popularnością $\mathrm{w}$ LN, brak sympatii w tychże gremiach odczuwał również sam Voldemaras. Pozytywne skutki płynące z przyjętej przez premiera Litwy linii prowadzenia polityki zagranicznej zauważalne były jedynie $\mathrm{w}$ relacjach $\mathrm{z}$ Niemcami, gdzie przyjęte porozumienia między tymi dwoma aktorami politycznymi przyniosły Litwie niemałe dotacje, pozwalające na rozwój programów publicznych, w tym rolniczych, rozwijających litewską gospodarkę. Zadowalające efekty płynące $\mathrm{z}$ prowadzonej przez Voldemarasa polityki zagranicznej, a pośrednio także gospodarczej, nie pozostały niezauważone przez prezydenta Smetonę oraz członków radykalnej części partii narodowców. Można przypuszczać, że Voldemaras spełnił pierwotne założenia Smetony, gdy ten podjął decyzję o powołaniu polityka na stanowisko premiera rządu i ministra spraw zagranicznych. Warto zwrócić uwagę, iż Voldemaras powinien zostać odwołany $\mathrm{z}$ pełnionej funkcji z uwagi na dopuszczenie się publicznej krytyki Smetony, prowadzonej przez niego polityki zagranicznej względem Polski i Rosji oraz polityki wewnętrznej. Jednak mimo tak odważnego wystąpienia przeciwko głównej postaci w państwie nie został usunięty ze stanowiska.

\section{Activity of Augustinas Voldemaras as the Author of Lithuanian Foreign Policy towards Poland, Germany, and the USSR in 1926-1929}

\section{Abstract}

Augustinas Voldemaras went down into history as the prime minister and foreign minister of Lithuania in 1918-1920 and 1926-1929. Undoubtedly, a characteristic feature of Voldemaras' policy was a special emphasis on the question of Polish-Lithuanian relations, mainly in the context of the Vilnius region. Equally important in Lithuanian foreign policy were secret negotiations with the Germans conducted with the aim to secure, among other things, additional

102 J. Purickis, Lietuvos užsienio prekyba. Pirmasis nepriklausomos Lietuvos desimtmietis, Vilnius 1990, s. 221. 
financial support for the young Lithuanian state, and the policy of détente with the USSR which made it possible for Lithuania to gain a powerful ally in the argument with Poland. This two-way policy based on manoeuvring between the Germans and the League of Nations combined with clearly anti-Polish overtones of Lithuanian foreign policy had a negative impact on Voldemaras' political image. This negative perception of his person in the international arena resulted in a gradual degradation of his authority and loss of confidence among the LN members, including Polish politicians. These questions are further developed in the article, shedding light on the aims and motivations of Voldemaras' policy towards Poland, Germany, Russia, and the League of Nations.

\section{Деятельность Аугустинаса Вольдемараса как создателя литовской внешней политики по отношению к Польше, Германии и СССР в 1926-1929 ГГ.}

\section{Аннотация}

Аугустинас Вольдемарас прославился на страницах истории как политик занимающий пост премьер-министра, а также главы литовского МИДа в 1918-1920 и 1926-1929 гг. Характерной особенностью внешней политики, проводимой Вольдемарасом, без сомнения, был большой упор, сделанный на вопрос польско-литовских отношений, главным образом, в контексте Виленщины. В равной степени существенными пунктами политической программы в области внешней политики являлись: проведение тайных переговоров с Германией, имевших целью, между прочим, приобретение дополнительной финансовой поддержки для молодого литовского государства, а также политика сближения с СССР, благодаря которой Литва обрела могущественного союзника в споре с Польшей. Двойственность политики, проводимой Вольдемарасом, опиравшейся на лавированию между Германией и Лигой наций а также заметный антипольский оттенок, реализованной им внешней политики, несомненно, негативно отпечатались на его политическом имидже. Негативное восприятие политика среди международной общественности, со временем, повлияло на постепенную деградацию его авторитета и потерю доверия среди членов Лиги наций, включая и польских политиков. Данное резюме будет развито в дальнейшей части работы, приближая, тем самым, цели и мотивы политики, проводимой Вольдемарасом, по отношению к Польше, Германии, России и Лиге наций.

\section{Bibliografia}

\section{Źródła}

Baczyński S., Dokumenty do pracy Litwa-Polska 1914-1927, Warszawa 1938.

Laroche J., Polska lat 1926-1935. Wspomnienia ambasadora francuskiego, przeł. i oprac. S. Zabiełło, Warszawa 1966.

Zaleski A., Przemowy i deklaracje, t. 1, Warszawa 1929.

\section{Opracowania}

Balutis B.K., Jo gyvenimas ir darba, Michigan 1951.

Budecki Z., Stosunki polsko-litewskie po wojnie światowej 1918-1928, Warszawa 1928. 
Butkus Z., Lenkijos agresijos grèsmé Lietuvai ir Latvijos pozicija 1927 m., t. 3, w: Mūsų praeitis, Vilnius 1993.

Eidintas A., Antanas Smetona ir jo aplinka, Vilnius 2012.

Garlicki A., Józef Piłsudski 1867-1935, Warszawa 1989.

Gorzuchowski S., Granica polsko-litewska w terenie, Warszawa 1928.

Gustainis V., Nuo Griškabūdžio iki Paryžiaus, Kaunas 1991.

Kasperavičius A., Naujausiujų laikų istorija, Vilnius 1993.

Klimas P., Lietuvos diplomatineje tarnyboje 1919-1940 m., Vilnius 1991.

Kuodys M., Kovos su antivalstybine propaganda Lietuvos kariuomenèje bruožai 1927-1940 m. karas. Karo archyvas, Kaunas 2014.

Łossowski P., Dylematy polsko-litewskie. Początki zatargu. Miejsce Józefa Piłsudskiego w konflikcie, w: Stosunki polsko-litewskie wczoraj i dziś. Historia, kultura, polityka, red. nauk. W.K. Roman, J. Marszałek-Kawa, Toruń 2009.

Łossowski P., Po tej i tamtej stronie Niemna. Stosunki polsko-litewskie 1883-1939, Warszawa 1985.

Łossowski P., Stosunki polsko-litewskie 1921-1939, Warszawa 1997.

Mitkiewicz L., Litwa i Polska. Stosunki wzajemne do roku 1939, Toruń 2018.

Navickas K., TSSR vaidmuo ginant Lietuva nuo imperialistines agresijos 1920-1940 metais, Vilnius 1966.

Purickis J., Lietuvos uzsienio prekyba. Pirmasis nepriklausomos Lietuvos desimtmietis, Vilnius 1990.

Senn A.E., The Great Powers, Lithuania and the Vilna Question 1920-1928, Leiden 1966.

Sidzikauskas V., Lietuvos diplomatijos paraštejje, Vilnius 1994.

Sierpowski S., Piłsudski w Genewie. Dyplomatyczne spory o Wilno w roku 1927, Poznań 1990.

Sirutavicius V., Nekrašas E., Lopata R., Svarbiausiosios Lietuvos Respublikos tarptautinơs sutartys 1918-1995 r., Vilnius 1997.

Skipitis R., Nepriklausoma Lietuva. Atsiminimai, Chicago 1967.

Skirius J., Lietuvos uztalantes diplomatija, 1918-1929 m., Vilnius 1995.

Skirpa K., Pakeliui su Mykolu Slezevicium, Chicago 1951.

Truska L., Antanas Smetona ir jo laikai, Vilnius 1996.

Vilkelis G., Lietuvos-Lenkijos konfliktas Tautu Sajungoje. istorijos krypties daktaro disertacijos santrauka, Vilnius 2006.

Voldemaras A., Pastabos saulèlydžio valandą, Vilnius 1992.

Wyszczelski L., Federacja czy inkorporacja, „Wojsko i Wychowanie” (1992), nr 4.

Žepkaité R., Diplomatija imperializmo tarnyboje, Vilnius 1980.

Žepkaité R., Konflikto tarp Lietuvos ir Lenkijos paastrejimas 1927 r. ir Tarybu Sajungos Pozicija, „Lietuvos istorijos metrastis” (1972).

Žiugžda R., Lietuva imperialistinių valstybiu planuose 1917-1940, Vilnius 1983.

Martinas Malužinas, mgr; Katedra Teorii Polityki i Myśli Politycznej Uniwersytetu Łódzkiego. Zainteresowania naukowe: upolitycznienie sportu, biografie polityczne, stosunki polsko-litewskie w dwudziestoleciu międzywojennym (martinasmaluzinas@gmail.com).

Martinas Malužinas, MA, Department of Theory of Politics and Political Thought, University of Lodz. His research interests Focus on: politicisation of sports, political biographies, Polish-Lithuanian relations in the interwar period (martinasmaluzinas@gmail.com). 